\title{
Journal of Clinical Case Reports
}

\section{Duodeno-Pancreatic Preservation in a Big Tumor of the Uncinate Process: A Tactic in Patients Previously Submitted to Total Colectomy} Kassab P*, Nara F, Ilias EJ, Castro OAP, Thuler FR, Freitas W, Mancini FC, da Silva PF and Malheiros CAM

Santa Casa of Sao Paulo Medical School, Brazil

\begin{abstract}
The possibility of preserving the duodenum and pancreas in the uncinate process neoplasms is, in general, reserved to less aggressive tumors. The literature describes this type of surgery for intraductal papillary mucinous neoplasms (IPMNs), or for cystic tumors.
\end{abstract}

Keywords: Duodenum; Pancreas; Pseudo papillary tumor; Pancreatic head

\section{Introduction}

The possibility of preserving the duodenum and pancreas in the uncinate process neoplasms is, in general, reserved to less aggressive tumors. The literature describes this type of surgery for intraductal papillary mucinous neoplasms (IPMNs), or for cystic tumors [1-3]. The Frantz neoplasm is a pseudo papillary tumor, more common in women, with an incidence of $1 / 3,200,000$. Its behavior is, in general benign, except in cases where the diagnosis is done too late.

In patients who had previously undergone a subtotal colectomy, the removal of the pancreatic head would cause severe metabolic and nutritional consequences and probably a chronic and with difficult control diarrhea. In those cases the duodenal preservation is always preferable.

\section{Case Report}

A 45 year-old woman presented with epigastric pain for three months and no other symptoms. She underwent 15 years before a subtotal colectomy with ileo-rectal anastomosis due to degenerated colonic polyposis. The physical examination did not show abnormalities and the magnetic resonance imaging (MRI) revealed a big solid mass in the uncinate process, apparently preserving the Wirsung duct (Figure 1).

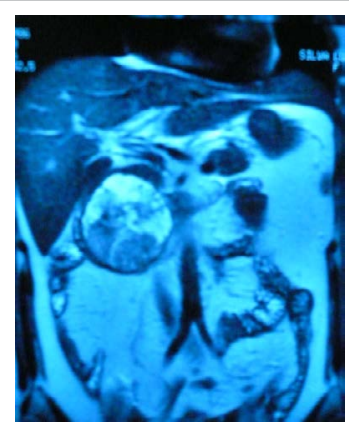

Figure 1: MRI revealing the tumor in the uncinate process.

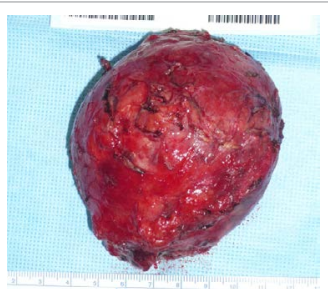

Figure 2: Specimen in the uncinate process.

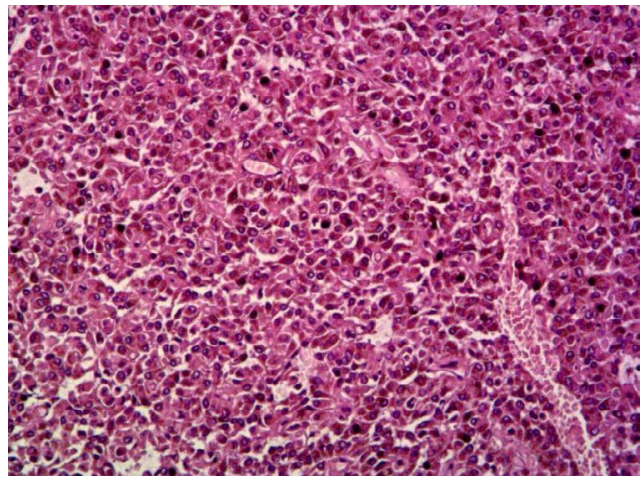

Figure 3: Pseudopapillae with hyalinized fibrovascular cores lined by several layers of epithelial cells with clear to eosinophilic cytoplasm and round/oval nuclei, finely stippled chromatin, nuclear grooves, indistinct nucleoli.

The resection of the pancreatic head and its impact in the quality of life (QoL) were exhaustively discussed with the patient who agreed with the surgery, but asked, if possible, to a less aggressive procedure. The access was done through a large bi subcostal incision, immediately followed by a cholecystectomy with a cholangiography to evaluate the common bile duct and, if possible the Wirsung duct. The macroscopic aspect indicated that it was a solid cystic tumor, allowing the team to perform a surgery with small margins. It was finally possible to excise only the mass and the uncinate process (Figure 2). The microscopic aspects are seen in Figures 3 and 4. A new cholangiography showed the integrity of the Wirsung duct. The postoperative period was uneventful and the patient is asymptomatic with 9 years of follow-up.

\section{Discussion}

The pancreatic head resection in patients previously submitted to total or subtotal colectomy, induces diarrhea extremely difficult to handle with bad QoL. In those cases, when possible, the pancreatic preservation should be attempted, obviously without compromising the oncologic results.

*Corresponding author: Paulo Kassab, PhD, MD, Faculdade de Ciencias Medicas da Santa Casa de Sao Paulo, Sao Paulo, SP Brazil, Tel: +55112135-0509; E-mail: paulokassab@terra.com.br

Received April 25, 2016; Accepted July 13, 2016; Published July 17, 2016

Citation: Kassab P, Nara F, llias EJ, Castro OAP, Thuler FR, et al. (2016) Duodeno-Pancreatic Preservation in a Big Tumor of the Uncinate Process: A Tactic in Patients Previously Submitted to Total Colectomy. J Clin Case Rep 6: 831. doi:10.4172/2165-7920.1000831

Copyright: (c) 2016 Kassab P, et al. This is an open-access article distributed under the terms of the Creative Commons Attribution License, which permits unrestricted use, distribution, and reproduction in any medium, provided the original author and source are credited. 


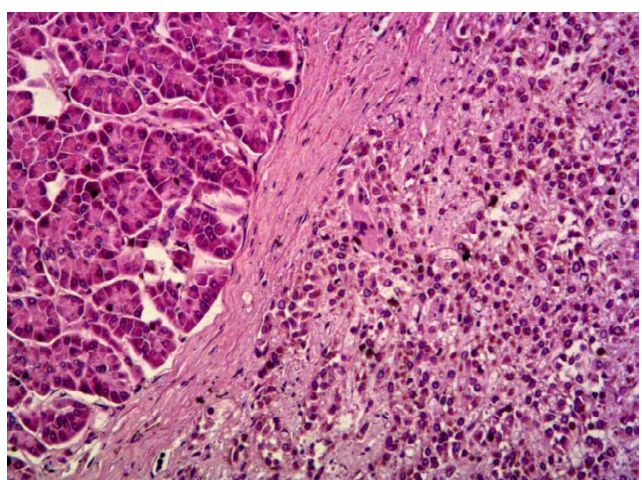

Figure 4: Frantz tumor - Tumor and normal pancreas separated by a capsule.

The solid cystic neoplasms-Frantz tumors-have a biological behavior not completely understood. It is more frequent in women and located in the body and pancreatic tail. Less than $30 \%$ are located in the pancreatic head and exceptionally in the uncinate process. Although it sometimes surpasses the organ limits, the vascular and adjacent organs invasion is very rare. Its behavior is benign except in the cases where the diagnosis is done too late and sometimes mistakenly and repeatedly treated as pseudocysts.

There are correlations between colonic polyposis and pancreatic malignant or benign neoplasms, nevertheless we did not find specific interconnection with the Frantz tumor [4]. In our report those two conditions were present: the patient had undergone a subtotal colectomy with ileo rectal anastomosis and in the case a pancreatectomy would be needed it would lead to severe nutritional and metabolic disorders. The appropriate treatment is still controversial with more or less extensive resections [5-14]. Considering the fact that $90 \%$ of the cystic pancreatic tumors are not invasive, they can be treated with more limited surgery, rather than extended pancreatectomies $[15,16]$. The importance of duodenal preservation in pancreatic surgery is that pancreatic enzyme secretion and endocrine function are not reduced after the procedure [17]. It is extremely important to exclude invasive tumors, which need to be treated in a radical way. Free margin resections without lymph node dissection are accepted from oncologic point of view, on the other hand, sometimes is difficult to have previously the histopathological results of the Frantz tumors. In those cases we give importance to the clinical and radiologic findings such as female gender and distinct margins in the CT scan or MRI [16].

Although the main surgical approach for pancreatic head tumors has been pancreaticoduodenectomy [18], the duodenum preserving pancreatectomies are being used more frequently for cystic neoplasms of the pancreatic head [19] and should be considered for they maintain the duodenum in the digestive transit, avoiding nutritional problems [3]. This is, however, a complex operation, due to the difficulties to preserve the duodenal vascularization, as well as the risk of intra and post-operative bleeding and fistulae $[1,2,20]$. Enucleation is being progressively accepted, especially in the small (less than $3 \mathrm{~cm}$ ) tumors. The comparison of 30 limited resections with 79 major pancreatectomies did not find statistical differences regarding mortality or fistulae, but it was noted a significant diminution in the morbidity, with better QoL and better functional results in the preservation group [21,22].

In spite of technical difficulties the partial resections should be attempted with extreme attention given to exclude malignancies [18]. In the present case there were strong evidences supporting the diagnosis of a solid cystic tumor, so the organ sparing surgery seemed more advisable, preserving almost entirely the pancreas and preserving the duodenum. Other important aspects during the surgery were: frozen section biopsies to confirm the absence of malignancy and the cholangiography to confirm that the Wirsung duct was not harmed.

We conclude that in patients previously submitted to total colectomy, the pancreatic head preservation is advisable in benign pancreatic head tumor.

\section{References}

1. Paik KY, Choi SH (2009) Experience of limited pancreatic head resection for management of branch duct intraductal papillary mucinous neoplasm in a single center. World J Gastroenterol 15: 2904-2907.

2. Tien YW, Hu RH, Hung JS, Wang HP, Lee PH (2008) Noninvasive pancreatic cystic neoplasms can be safely and effectively treated by limited pancreatectomy. Ann Surg Oncol 15: 193-198.

3. Beger HG, Gansauge F, Siech M, Schwarz M, Poch B (2008) Duodenumpreserving total pancreatic head resection for cystic neoplastic lesions in the head of the pancreas. J Hepatobiliary Pancreat Surg 1: 149-156.

4. Elkharwily A, Gottlieb K (2008) The Pancreas in Familial Adenomatous Polyposis. JOP 9: 9-18.

5. Spinelli KS, Fromwiller TE, Daniel RA, Kiely JM, Nakeeb A et al. (2004) Cystic pancreatic neoplasms: observe or operate. Ann Surg 39: 651-657.

6. Horvath KD, Chabot JA (1999) An aggressive resectional approach to cystic neoplasms of the pancreas. Am J Surg 178: 269-274.

7. Siech M, Tripp K, Schmidt-Rohlfing B, Mattfeldt T, Widmaier $U$ et al. (1998) Cystic tumours of the pancreas: diagnostic accuracy, pathologic observations and surgical consequences. Langenbecks Arch Surg 383: 56-61.

8. Ooi LL, Ho GH, Chew SP, Low CH, Soo KC (1998) Cystic tumours of the pancreas: a diagnostic dilemma. Aust N Z J Surg 68: 844-846.

9. Walsh RM, Vogt DP, Henderson JM, Zuccaro G, Vargo J (2005) Natural history of indeterminate pancreatic cysts. Surgery 138: 665-670.

10. Handrich SJ, Hough DM, Fletcher JG, Sarr MG (2005) The natural history of the incidentally discovered small simple pancreatic cyst: long-term follow-up and clinical implications. AJR Am J Roentgenol 184: 20-23.

11. Allen PJ, D Angelica M, Gonen M, Jaques DP, Coit DG (2006) A selective approach to the resection of cystic lesions of the pancreas: results from 539 consecutive patients. Ann Surg 244: 572-582.

12. Brugge WR, Lauwers GY, Sahani D, Fernandez-del Castillo C, Warshaw AL (2004) Cystic neoplasms of the pancreas. N Engl J Med 351: 1218-1226.

13. Sahani DV, Saokar A, Hahn PF, Brugge WR, Fernandez-Del Castillo C (2006) Pancreatic cysts $3 \mathrm{~cm}$ or smaller: how aggressive should treatment be? Radiology 238: 912-919.

14. Nachulewicz P, Rogowski B, Obel M, Wozniak J (2015) Central Pancreatectomy as a Good Solution in Frantz Tumor Resection: A Case Report. Medicine (Baltimore) 94: e1165

15. Allen PJ, Jaques DP, D’Angelica M, Bowne WB, Conlon KC, et al. (2003) Cystic lesions of the pancreas: selection criteria for operative and nonoperative management in 209 patients. J Gastrointest Surg 7: 970-977.

16. Castillo CF, Targarona J, Thayer SP, Rattner DW, Brugge WR, et al. (2003) Incidental pancreatic cysts: clinicopathologic characteristics and comparison with symptomatic patients. Arch Surg 138: 427-434.

17. Resende V, Azevedo PH, Lima Ldo P, Portela AR, Sanches MD (2014) Duodenum-preserving pancreatic head resection in solid pseudopapillary neoplasm-Report of a case. Int J Surg Case Rep 5: 567-570.

18. Yuan CH, Tao M, Jia YM, Xiong JW, Zhang TL, et al. (2014 ) Duodenumpreserving resection and Roux-en-Y pancreatic jejunostomy in benign pancreatic head tumors. World J Gastroenterol 20: 16786-16792.

19. Beger HG, Schwarz M, Poch B (2012) Duodenum-preserving total pancreatic head resection for benign cystic neoplastic lesions. J Gastrointest Surg 16 2160-2166

20. Schmitt F, Maignan A, Ploteau S, Hamel A, Lagier S, et al. (2010) New anatomical data on the drainage patterns of the uncinate process of the pancreas. Surg Radiol Anat. 32: 777-781 
Citation: Kassab P, Nara F, llias EJ, Castro OAP, Thuler FR, et al. (2016) Duodeno-Pancreatic Preservation in a Big Tumor of the Uncinate Process: A Tactic in Patients Previously Submitted to Total Colectomy. J Clin Case Rep 6: 831. doi:10.4172/2165-7920.1000831

21. Hwang HK, Park JS, Kim JK, Park CM, Cho IS, et al. (2012) Comparison of Efficacy of Enucleation and Pancreaticoduodenectomy for Small $(<3 \mathrm{~cm})$ Branch Duct Type Intraductal Papillary Mucinous Neoplasm Located at the Head of Pancreas and the Uncinate Process. Yonsei Med J 53: 106-110
22. Tsuchikawa T, Hirano S, Tanaka E, Kato K, Matsumoto J, et al. (2013) Modified duodenum-preserving pancreas head resection for low-grade malignant lesion in the pancreatic head. Pancreatology 13:170-174 